\title{
Agroclimatic zoning: a planning strategy for agricultural and livestock systems in Alta Guajira, Colombia
}

\section{Zonificación agroclimática: una estrategia de planificación para sistemas agrícolas y pecuarios en la Alta Guajira, Colombia}
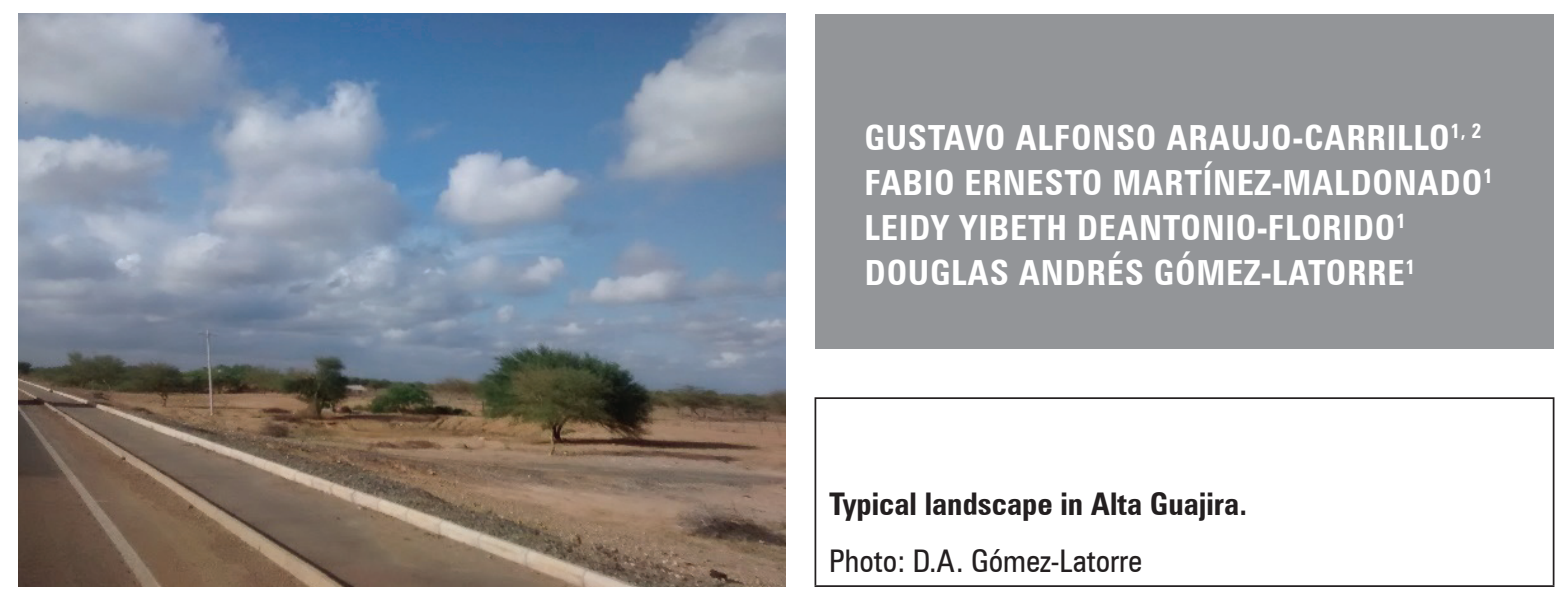

\section{ABSTRACT}

One of the most important dry agroecosystems in Colombia is found in the northern Guajira region, which has native inhabitants (sociocultural aspect) and semiarid zones (ecological aspect). This condition has resulted in great vulnerability in agricultural production systems to adverse climatic events, which require large scale action. For example, the establishment of agroclimatic suitability zones are needed to access information, for decision-making. The aim of this study was to carry out agroclimatic zoning in the municipality of Uribia (La Guajira) for agricultural production systems and animal feed species. The criteria used to identify the agroclimatic suitability zones included: plant coverage present in the municipality, soil suitability, water storage under water stress, regular conditions found in the municipality, and an extreme water deficit event. The evaluated conditions showed variations in agroclimatic suitability during the periods January to April and August to November. During an extreme water-deficit event between August and November, the suitable area for the establishment of production systems with plant species (type C3 and C4) was smaller (77,000 ha) than in the period January to April (130,000 ha). The agroclimatic suitability categories in Uribia did not exhibit differences between the evaluated periods under average water-deficit conditions.

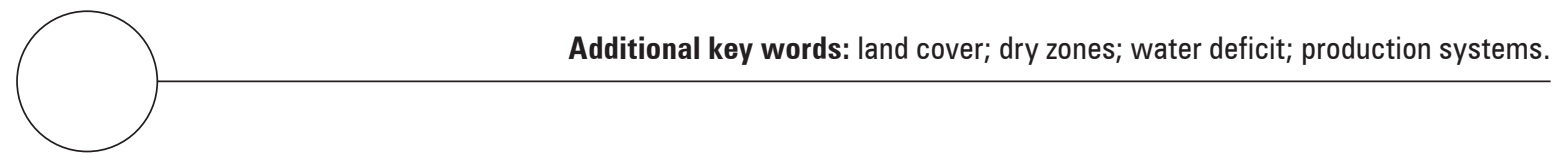

Colombian Corporation for Agricultural Research (Agrosavia), Tibaitata Research Center, Mosquera (Colombia). ORCID Araujo-Carrillo, G.A.: 0000-0003-4314-615X; ORCID Martínez-Maldonado, F.E.: 0000-0002-1244-5897; ORCID Deantonio-Florido, L.Y.: 0000-0002-8520-1340; ORCID Gómez-Latorre, D.A.: 0000-0002-6067-7596

2 Corresponding author. garaujo@agrosavia.co 


\section{RESUMEN}

En el norte de la Guajira encontramos uno de los ecosistemas secos más importantes de Colombia desde el punto de vista sociocultural y ecológico. Esta condición genera una gran vulnerabilidad de sus sistemas agropecuarios a eventos climáticos extremos, razón por la cual varias acciones son requeridas para reducirla. Dentro de las acciones se encuentra el establecimiento de zonas de aptitud agroclimática, una fuente de acceso a información que permite tomar decisiones. El objetivo de este estudio fue realizar una zonificación agroclimática del municipio de Uribia (La Guajira) para sistemas de producción agrícola y especies de alimentación animal. Los criterios utilizados para realizar la identificación de las zonas de aptitud incluyeron: coberturas vegetales presentes, aptitud de suelos, almacenamiento de agua bajo estrés hídrico, condiciones regulares climáticas y un evento de déficit hídrico extremo. Las condiciones evaluadas registraron variaciones en la aptitud agroclimática desde enero a abril y desde agosto a noviembre. Bajo la condición de déficit hídrico extremo entre agosto y noviembre, el área apta para el establecimiento de sistemas de producción con especies agrícolas (tipo C3 y C4) fue menor (77.000 ha) comparado con el periodo de enero a abril (130.000 ha). Las categorías de aptitud agroclimática en Uribia no mostraron diferencias entre los períodos evaluados bajo condiciones de déficit hídrico promedio.

Palabras clave adicionales: cobertura de la tierra; zonas secas; déficit hídrico; sistemas productivos.

Received for publication: 18-09-2019 Accepted for publication: 29-11-2019

\section{INTRODUCTION}

There are several incompatibilities between environmental offerings and areas used for agricultural activities since, in many cases, these activities are carried out in areas that experience major climatic threats, such as water deficiencies or excess water in the soil, frosts, and floods, among others (Brown and Raymond, 2014; Kim and Arnbold, 2018). Likewise, the socioeconomic development of communities or producers located in threatened areas suffers high vulnerability, generating inequity in the distribution of resources (Magrin, 2015; Cleves-Leguízamo et al., 2017).

The municipality of Uribia in the Department of La Guajira has a desert climate, with annual precipitation averages between 300 and $600 \mathrm{~mm}$ and an evapotranspiration of $2,000 \mathrm{~mm}$, which constantly generates water deficit conditions throughout the region (Corpoica, 2016). This situation puts at least 105,000 people of the indigenous Wayúu population who depend mainly on goat production systems at risk.

Rudimentary agricultural practices result in high vulnerability to seasonal rainfall variability and extreme weather events. The third national agricultural census (CNA) for year 2013 recorded 173,134 sheep (mostly Ovies aries "camuro" breed) and 243,351 goats (mostly Capra aegagrus hircus "guajira" or "criolla" breed) for this municipality, a ratio of 1:1.4 (DANE, 2014), associated with regular land use patterns such as transhumance. The main sources of animal feed are pastures and shrubs, so the mobility and diet of the animals depend on the scarce distribution and variability of plant species (Steinfeld et al., 1996; Shinde et al., 1998; Oba et al., 2000).

Agroclimatic-zoning studies contribute to agricultural system adaptation since they provide information for the planning of agricultural activities and establish incompatible uses that negatively affect sustainability and competitiveness (Gelcer et al., 2018). Furthermore, they incorporate climatic and agroclimatic indicators that are useful for identifying potential areas in the establishment of production systems and contribute to the generation of strategies for climate change and variability prevention and adaptation (Basualdo et al., 2015).

Zoning based on the climatic variables of solar radiation, temperature, and precipitation (Arce and Uribe, 2015), as well as the evapotranspiration of the reference crop $\left(\mathrm{ET}_{0}\right)$ (Allen et al., 1998), are determining factors in the behavior analysis of plants or agricultural crops of interest with climatic variability events and in the study of adaptation mechanisms for food production. Average values of these elements have 
been used in countless zoning studies for multiple crops, usually based on methodologies such as agroecological zoning or AEZ (FAO, 1996; Fischer and Velthuizen, 2002).

Some agroclimatic zoning analyses include factors such as thermal supply and water availability on daily or decadal scales and specific aspects of crop physiology and edaphoclimatic requirements (Brunini et al., 2001). Others incorporate thematic layers that characterize the territory, such as land cover, obtained primarily from the performance of land resource inventories (FAO, 1996). Moreover, many studies have adopted methods for analyzing suitability through geographic information system (GIS) methodologies, following multicriteria decision-making approaches in different situations (Amiri et al., 2012; Kioko et al., 2012; Zhang et al., 2014; Keno and Suryabhagavan, 2015).

Martínez et al. (2016) conducted territorial studies of water excess and deficiency susceptibility in soil in order to construct an agroclimatic zoning methodology. They performed their analysis based on the conceptualization of agroclimatic risks by Field et al. (2012), integrating the soil requirements of a tomato crop and the monthly probability of the occurrence of moisture conditions in a soil with a water deficit. The water deficit analysis was done with a data series from the period between 1980 and 2011 using the Palmer Drought Severity Index (PDSI) during each of the crop development-cycle months. This methodology identified "productive niches" or potential areas for tomato production, i.e. areas that exhibited low soil limitations and low water deficit probability in the soil.

Given the importance of this region in Colombia given the dry agroecosystem characteristics, the type of natural cover, and the high degree of vulnerability, the aim of this study was to carry out agroclimatic zoning of the municipality of Uribia in order to define suitable agricultural development areas under conditions of a water deficit in the soil.

\section{MATERIALS AND METHODS}

\section{Study area}

Uribia is in the northernmost region of the Department of La Guajira, Colombia, between longitudes $71^{\circ} 05^{\prime}$ and $72^{\circ} 23^{\prime} \mathrm{W}$ and latitudes $11^{\circ} 31^{\prime}$ and $12^{\circ} 28^{\prime}$ N, with an area of 787,202 ha (Fig. 1). Strong trade winds from the northeast, sand displacement, and low total annual precipitation volumes $(<500 \mathrm{~mm})$ result in a tropical desert biome with accentuated aridity conditions.

The driest season of the year, when water deficiency conditions intensify, occurs between December and March as a consequence of dry northeast winds and the displacement of the ITCZ (Intertropical Convergence Zone) to the south. The rainy season occurs between August and November, as the ITCZ reaches its northernmost position (Eslava, 1993; Mesa et al., 1997).

The $\mathrm{ET}_{0}$ is always greater than the average rainfall, and moisture storage in the soil is minimal or null since the entire available supply is consumed by the high atmospheric demand. The soils are sodium saline, vulnerable to erosion, and have relatively limited fertility. The existing vegetation cover, dominated by desert scrub and sub-xerophytic forests, is subject to high temperatures (Pinilla and Zuluaga, 2014).

\section{Agroclimatic zoning}

The zoning was based on an analysis of land use suitability using the land evaluation scheme (ET) published by FAO (1976), the calculation of the probability of the occurrence of water deficit conditions in the soil based on the PDSI (Palmer, 1965), the study carried out by Martínez et al. (2016), and the availability and type of plant cover using Corine Land Cover (CLC) (IDEAM, 2012). Then, these analyses were integrated into monthly agroclimatic scenarios (AS). Finally, the AS was used to generate the agroclimatic zoning.

\section{Land use suitability}

The land use suitability for the plant species of interest (crops, pastures, and forages) in the agricultural production systems of Uribia was evaluated. The ET methodology was implemented on a general scale (1: 100,000), and physical and chemical soil characteristics were considered, as well as slope and natural drainage conditions, factors that are decisive for the development of agricultural activities. The information source for this evaluation was the general soil survey carried out by IGAC (2009) in the Department 


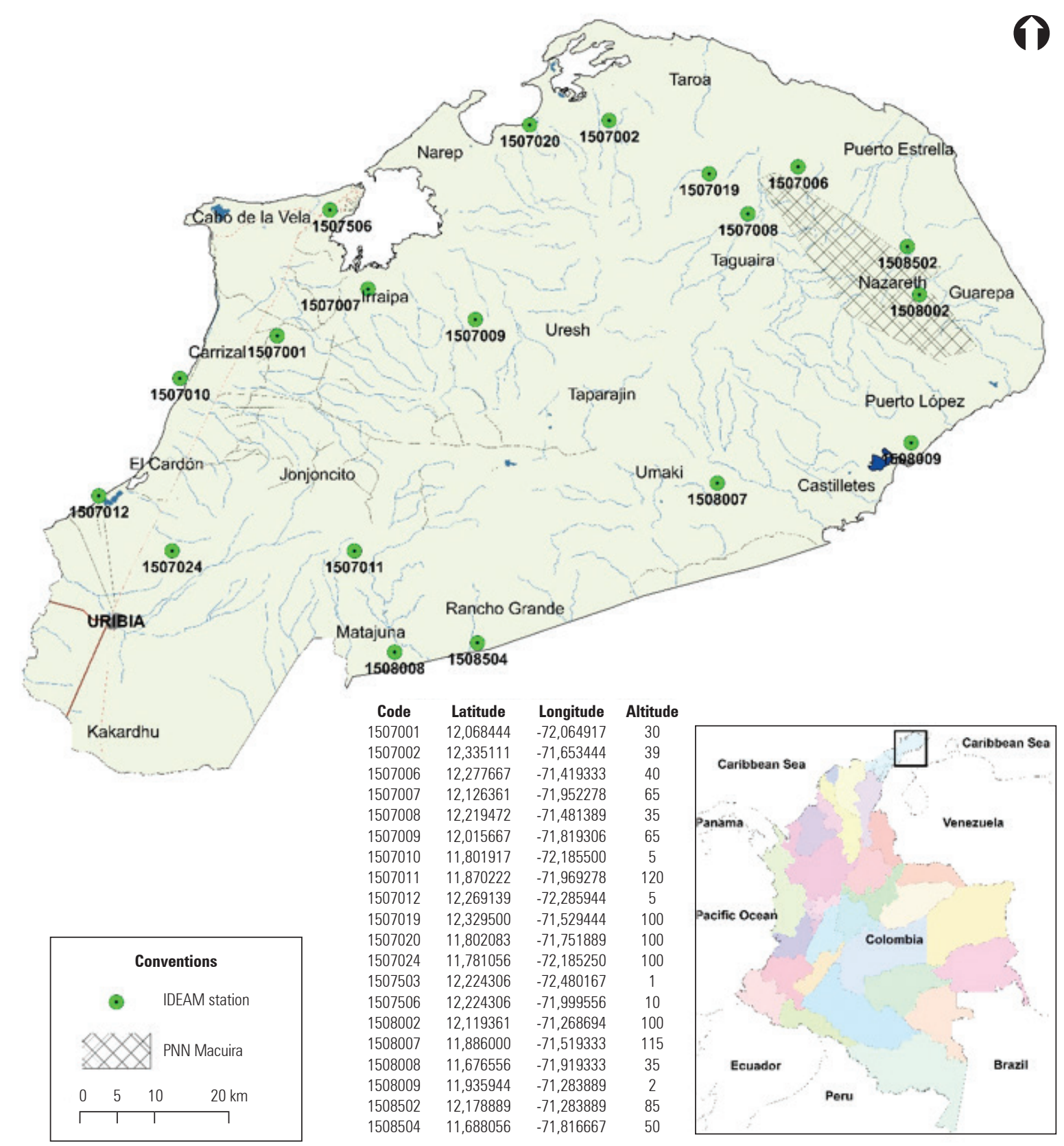

Figure 1. Location of meteorological stations used for agroclimatic zoning in the municipality of Uribia (PNN: National Natural Park).

of La Guajira, with which the soil offer of land units (UdT) was identified. The edaphic requirements for the development of the agricultural systems were elucidated by consulting secondary information based on the databases of FAO and the Colombian Corporation for Agricultural Research (Agrosavia).
A decision tree was generated in order to determine soil suitability, divided into optimal (A1), moderate (A2), marginal (A3), and unsuitable (N) classes. After the identification of these use suitability classes in the municipality, they were grouped into three categories: suitable soils (classes A1 and A2), soils 
conditioned to management practices (with severe restrictions depending on the evaluated variables) (classes A2 and A3), and unsuitable soils (classes A3 and $\mathrm{N}$ ).

\section{Soil humidity conditions}

The occurrence frequency of average water-deficit conditions was established, i.e. the prevalent condition in Uribia and the extreme water deficit in the soil associated with climate variability events such as the El Niño phenomenon. The monthly data series of precipitation, average maximum, medium and minimum temperature, relative humidity, and solar brightness was determined for the period 1980 to 2011. The information was gathered from 20 stations belonging to the meteorological observation network of the Colombian Institute of Hydrology, Meteorology, and Environmental Studies (IDEAM) in the study area (Fig. 1).

Based on the methodology of Martínez et al. (2016), the PDSI was calculated (Palmer, 1965), and index values were established for the average water deficit in Uribia (between -2.00 and 0.50) and for the extreme water deficit in this region (less than -2.00) (Tab. 1). Frequencies were calculated for the periods January to April (JFMA), the driest period of the year, and August to November (ASON), the rainiest period.

\section{Table 1. PDSI categories that indicate average water defi- cit and extreme water deficit conditions for agri- cultural production systems in Uribia.}

\begin{tabular}{|c|c|c|c|}
\hline $\begin{array}{c}\text { PDSI } \\
\text { category }\end{array}$ & Value & $\begin{array}{l}\text { Soil humidity } \\
\text { condition }\end{array}$ & $\begin{array}{l}\text { Index ranges } \\
\text { and thresholds }\end{array}$ \\
\hline Normal & $(-0.50-0.50]$ & \multirow{3}{*}{$\begin{array}{c}\text { Average water } \\
\text { deficit }\end{array}$} & \multirow{3}{*}{$-2.00-0.50$} \\
\hline Incipient & $(1.00--0.50]$ & & \\
\hline Reduced & $(-2.00--1.00]$ & & \\
\hline Moderate & $(-3.00--2.00]$ & \multirow{3}{*}{$\begin{array}{c}\text { Extreme water } \\
\text { deficit }\end{array}$} & \multirow{3}{*}{$<-2.00$} \\
\hline Severe & $(-4.00--3.00]$ & & \\
\hline Extreme & $\leq-4.00$ & & \\
\hline
\end{tabular}

Based on the frequency of occurrence of the PDSI values from each of the climatological stations, the monthly probability of average water deficit was established for each four-month period, taking into account the entire series. Only PDSI values lower than
-0.5 were assessed for extreme water deficit. Then, five levels were established in order to determine the frequency of occurrence of each water deficit condition as follows: very low (0-20\%); low (20-40\%); medium (40-60\%); high (60-80\%) and very high (80-100\%).

\section{Land cover}

The different land cover types in the municipality were identified based on the thematic layer of land cover for the period 2005-2009 at a scale of 1:100,000, generated with the CLC methodology (IDEAM, 2012). The land cover types were classified into three categories based on their level of limitation for implementing agricultural systems (Tab. 2).

\section{Table 2. Limitation category for conserving water in the soil according to the cover type.}

\begin{tabular}{|c|c|}
\hline $\begin{array}{l}\text { Limitations for } \\
\text { agricultural } \\
\text { systems }\end{array}$ & Coverage type \\
\hline \multirow{5}{*}{ High } & Sandy areas \\
\hline & Sandbanks \\
\hline & Dune fields \\
\hline & Rocky outcrop \\
\hline & Bare and degraded lands \\
\hline \multirow{2}{*}{ Medium } & Herbaceous open land \\
\hline & Open shrubland \\
\hline \multirow{13}{*}{ Low } & Clean pastures \\
\hline & Crop mosaic \\
\hline & Pasture and crop mosaic \\
\hline & Crop, pasture and natural spaces mosaic \\
\hline & Pasture mosaic with natural spaces \\
\hline & Low dense forest \\
\hline & Low open forest \\
\hline & Fragmented forest with pastures and crops \\
\hline & Fragmented forest with secondary vegetation \\
\hline & Gallery and riparian forests \\
\hline & Dense herbaceous land \\
\hline & Dense shrubland \\
\hline & Secondary or transition vegetation \\
\hline
\end{tabular}




\section{Monthly agroclimatic scenarios}

Agroclimatic scenarios (AS) constitute a spatial monthly representation where use suitability, soil moisture conditions, and land coverage are integrated. The AS were constructed by overlapping with GIS geoprocessing tools, showing the behavior and dynamics of the soil moisture (extreme and average water deficit) during the analyzed periods (JFMA and ASON).

\section{Agroclimatic suitability}

The areas with a low water deficit exposure were identified with the AS, that is, the areas that persistently exhibited a low and medium average water deficit and extreme water deficit frequencies of occurrence. The agroclimatic suitability was classified into six categories according to the ranges established in a qualification matrix (Tab. 3).

Finally, four agroclimatic suitability maps for agricultural systems in Uribia were elaborated.

\section{RESULTS AND DISCUSSION}

\section{Soil use suitability}

Most of the Uribia area exhibited restricted conditions for establishing and developing agricultural systems since more than $80 \%$ of the soils exhibited marginal suitability or were not suitable for agricultural uses. Only $3.7 \%$ of the soils were suitable (A1), while $15 \%$ had moderate suitability (A2), 31.5\% were marginal (A3), and most, i.e. $49.8 \%$, were not suitable (Fig. 2).

\section{Humidity condition}

\section{Average water deficit}

During the dry quarter, JFMA, the probability of occurrence of an average water deficit was mainly medium (40-60\%) (Fig. 3: A, B, C, and D). The water deficit probability increased in February and March as a result of intensification of the dry period.

Table 3. Agroclimatic suitability qualification categories for goat production in the municipality of Uribia.

\begin{tabular}{|c|c|c|c|}
\hline Category & Soil use suitability (FA0) & $\begin{array}{l}\text { Coverage } \\
\text { limitation }\end{array}$ & $\begin{array}{c}\text { Average/extreme } \\
\text { water deficit probability }\end{array}$ \\
\hline \multirow{2}{*}{$\begin{array}{l}\text { Areas recommended for goat production, } \\
\text { and with potential for the establishment of } \\
\text { plant cover }\end{array}$} & Optimal with low restrictions & \multirow{2}{*}{ Low and medium } & \multirow{2}{*}{ Very low, low, medium (<60\%) } \\
\hline & Conditioned to management practices & & \\
\hline \multirow{2}{*}{$\begin{array}{l}\text { Areas limited by low or no current vege- } \\
\text { tation cover, and with potential for the } \\
\text { establishment of plant cover }\end{array}$} & Optimal with low restrictions & \multirow{2}{*}{ High } & \multirow{2}{*}{ Very low, low, medium $(<60 \%$} \\
\hline & Conditioned to management practices & & \\
\hline \multirow{2}{*}{$\begin{array}{l}\text { Areas limited by high exposure to water } \\
\text { deficit }\end{array}$} & Optimal with low restrictions & \multirow{2}{*}{ Low and medium } & \multirow{2}{*}{ High, very high (>60\%) } \\
\hline & Conditioned to management practices & & \\
\hline \multirow{4}{*}{ Areas not recommended for goats } & Not recommended (unsuitable) & \multirow{3}{*}{ High } & \multirow{3}{*}{ High, very high (>60\%) } \\
\hline & Optimal with low restrictions & & \\
\hline & Conditioned to management practices & & \\
\hline & Not recommended (unsuitable) & High & Very low, low, medium (<60\%) \\
\hline $\begin{array}{l}\text { Areas for current goat use and with soil } \\
\text { limitations for the establishment of plant } \\
\text { cover }\end{array}$ & Not recommended (unsuitable) & Low and medium & Very low, low, medium (<60\%) \\
\hline $\begin{array}{l}\text { Areas for current goat use and with low } \\
\text { potential for the establishment of plant } \\
\text { cover }\end{array}$ & Not recommended (unsuitable) & Low and medium & Very low, low, medium (>60\%) \\
\hline
\end{tabular}



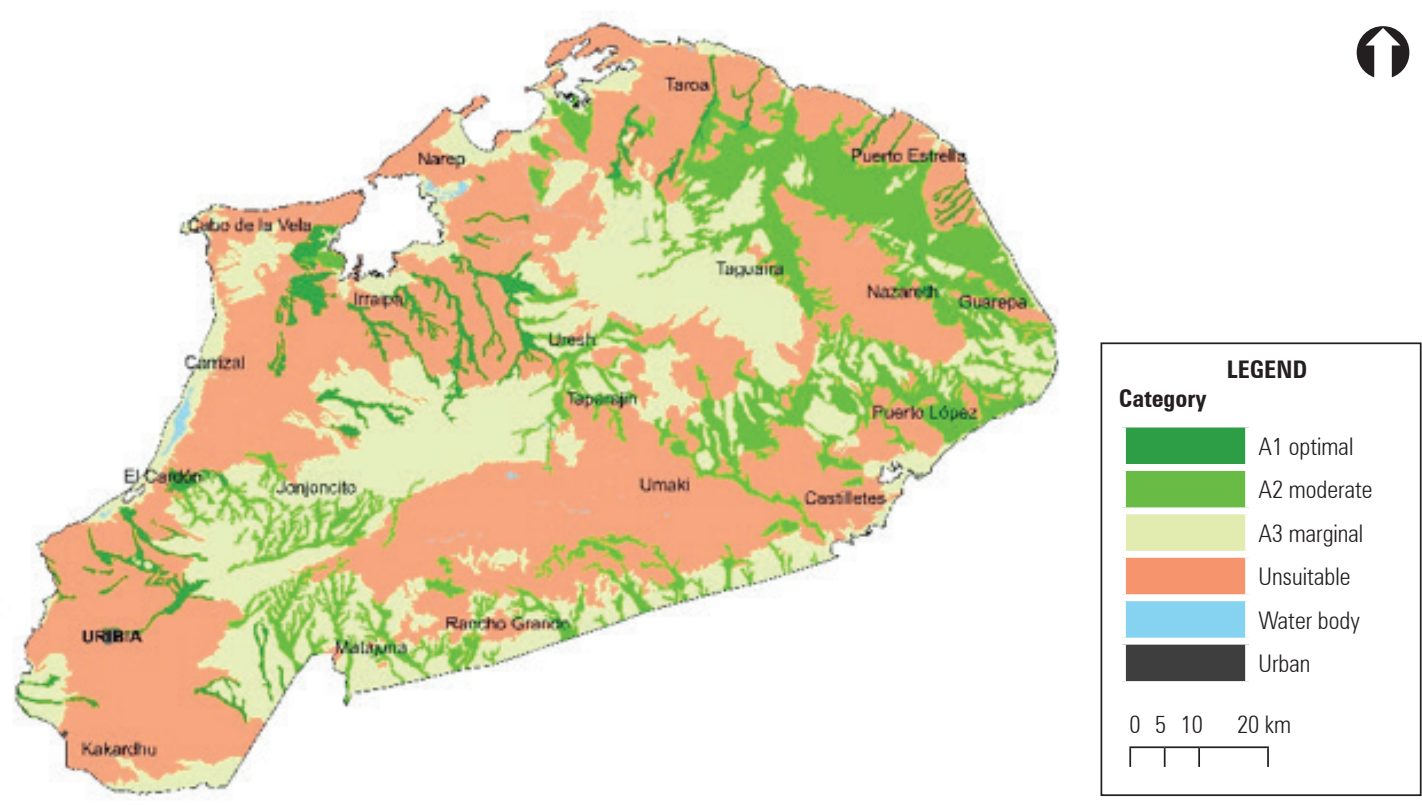

Figure 2. Soil suitability classification for agricultural uses in the municipality of Uribia.

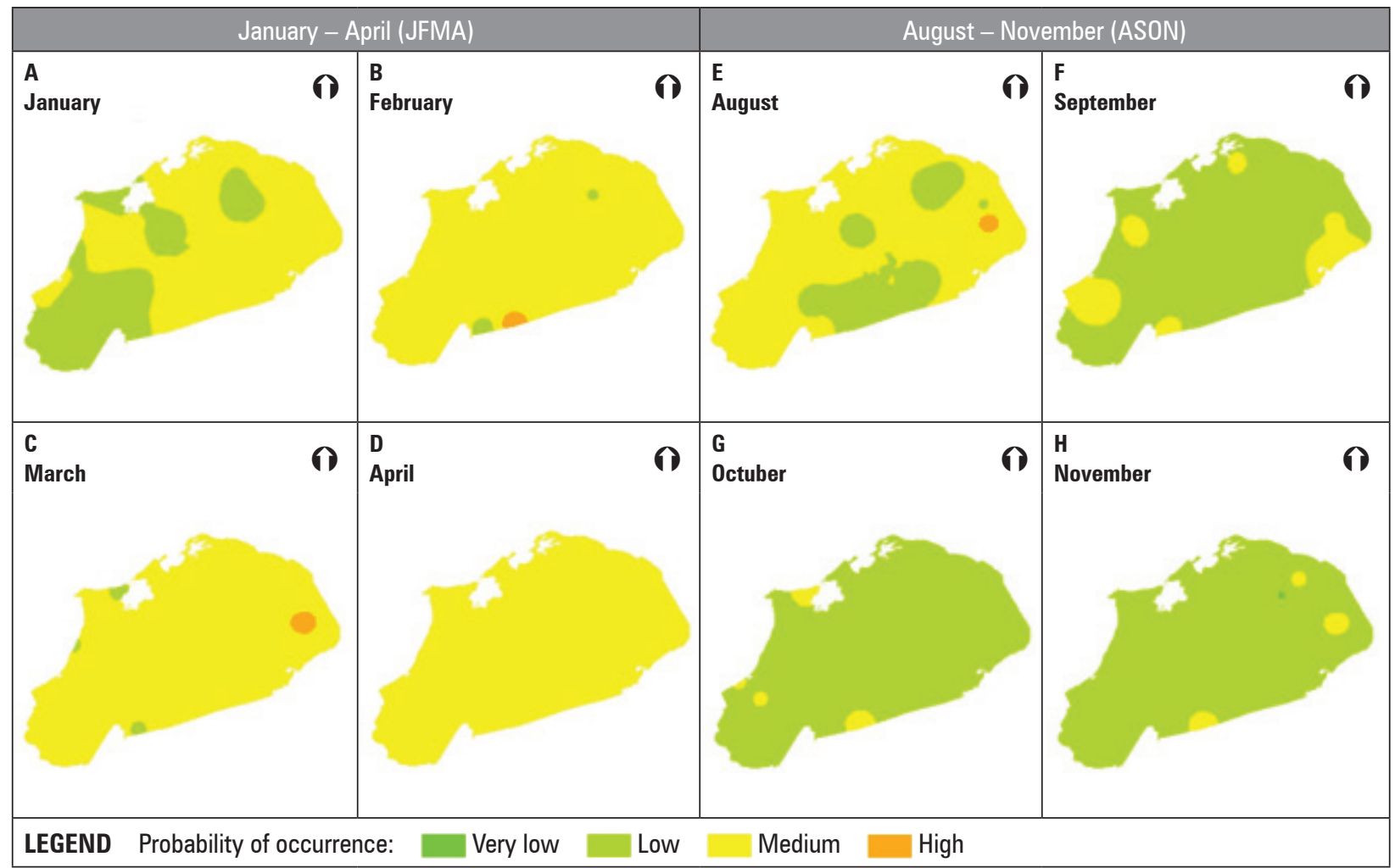

Figure 3. Monthly frequency of occurrence of average water deficit conditions in the soil of Uribia during the dry (JFMA) and the rainy (ASON) periods. 
By contrast, during the ASON period, low probabilities of the occurrence of an average water deficit occurred in most of the municipality. Furthermore, during the months of September, October, and November, the probabilities did not exceed $40 \%$ (Figs. 3: E, F, G, and $\mathrm{H})$.

\section{Extreme water deficit}

The frequency of occurrence of an extreme water deficit was mainly average (40\%-60\%) during the two periods (Fig. 4: A, B, C, and D). In comparison with the January-April period, during the rainy fourmonth period, a larger area of the municipality was exposed to a high frequency $(60 \%-80 \%)$ of extreme water deficit conditions, mainly during October and November (Figs. 4: E, F, G, and H).

\section{Land coverage}

Shrub vegetation represents the most abundant cover type $(48.4 \%)$ in Uribia, followed by the coverage associated with bare and degraded lands (25.6\%). Thirty-four categories of land use were identified in the municipality and reclassified according to the limitations (Fig. 5).

\section{Agroclimatic suitability for agricultural systems}

\section{Average water deficit condition}

Under average water deficit conditions, approximately 171,000 ha (22\% of the municipality) were identified as "areas recommended for goat production with potential for the establishment of vegetation cover" in the two evaluated periods (Fig. 6: A and B, and Tab. 4). These areas exhibited fewer limitations for the establishment and management of smaller species (i.e. goats). Moreover, they exhibited dense and continuous coverage (grasslands, shrubs, forests, pastures, and some crops) that provide a viable food supply for goats. They exhibited optimal soils for the system or for effective depth management practices:

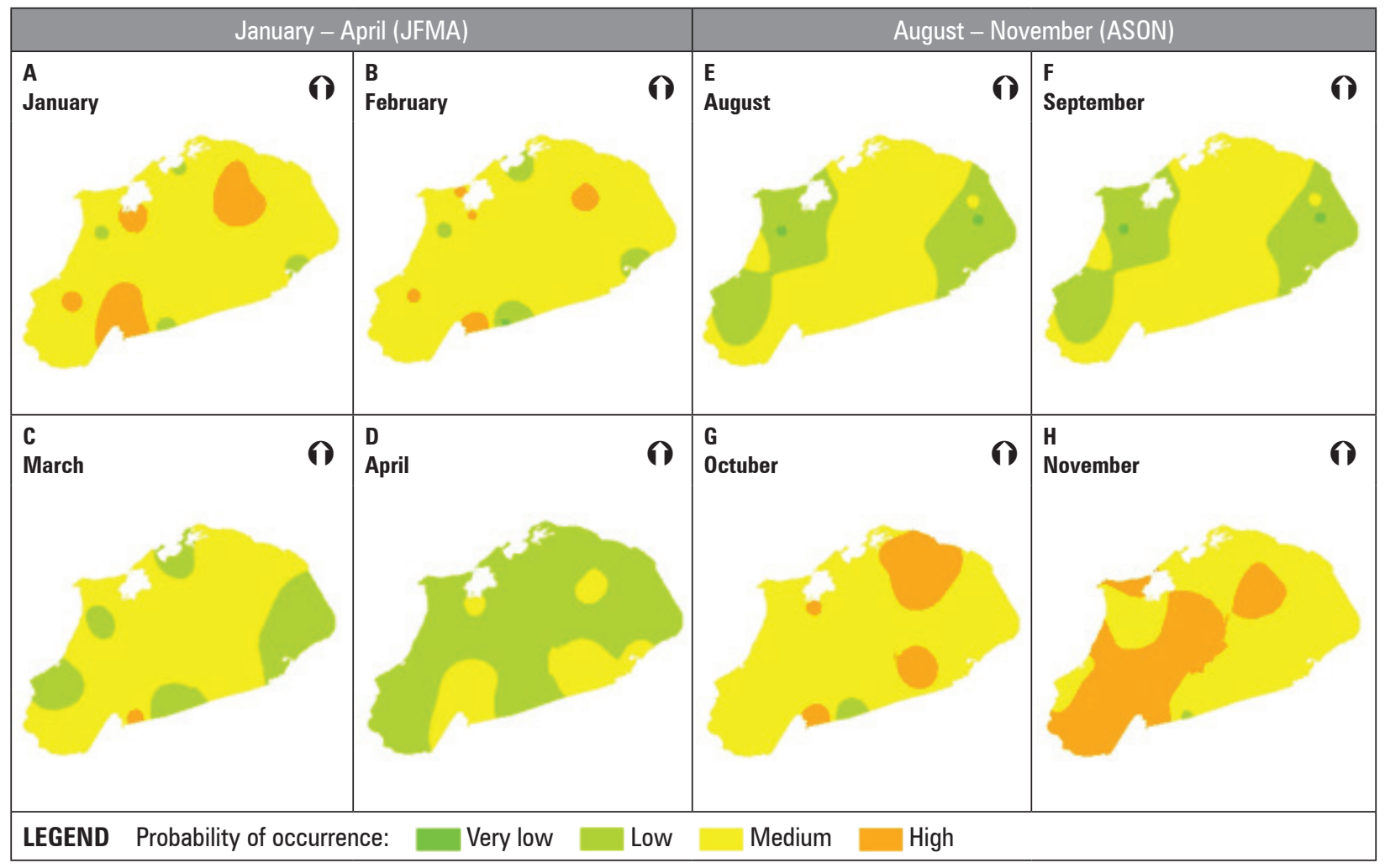

Figure 4. Monthly frequency of occurrence of extreme water deficit conditions in the soil of Uribia during the dry (JFMA) and the rainy (ASON) periods. 


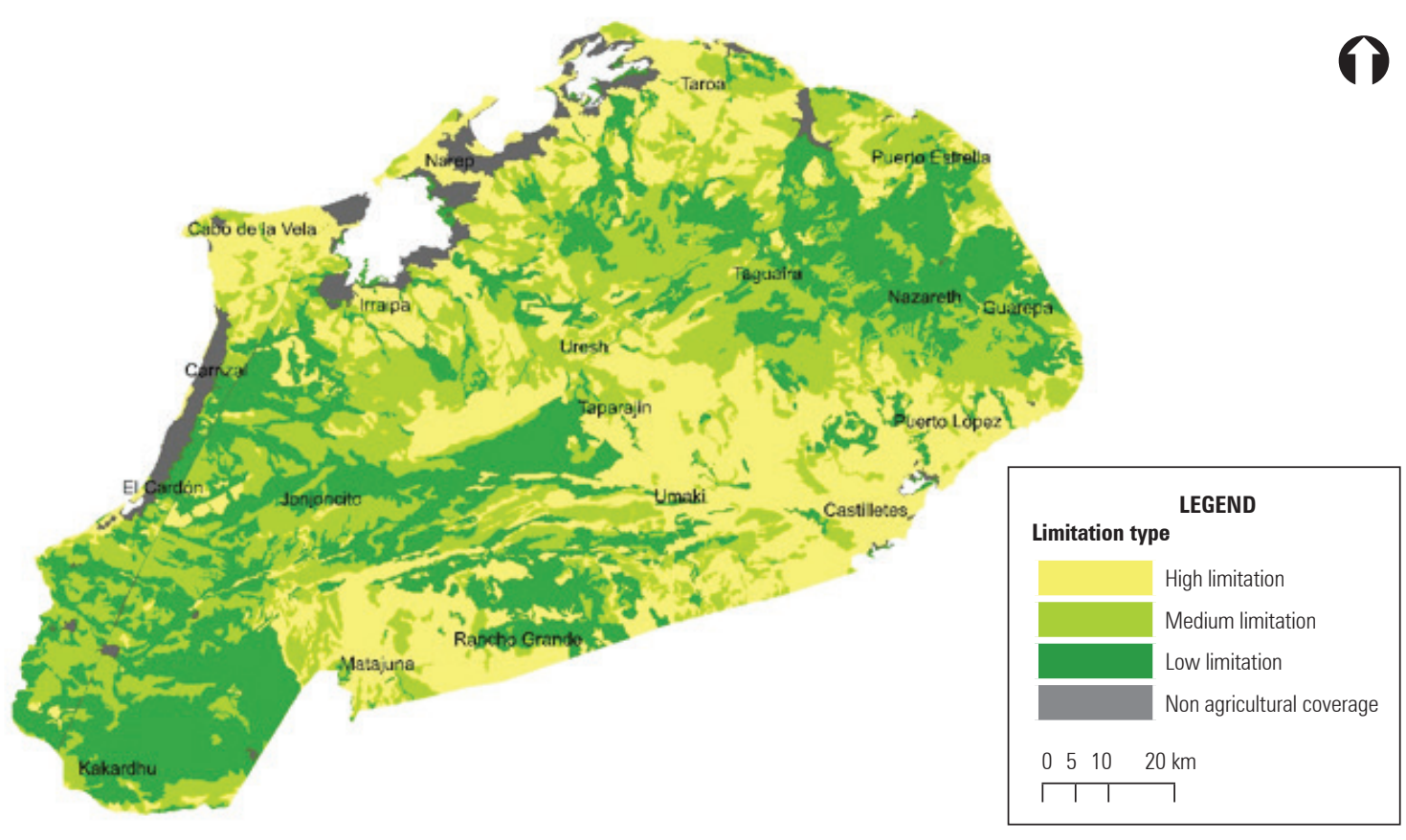

Figure 5. Land cover classification in the municipality of Uribia according to limitations for the conservation of water in the soil.

coarse textures, alkaline $\mathrm{pH}$, compacted horizons, excessive drainage, salinity, and sodium content. The frequency of average water deficit conditions was predominantly low $(<40 \%)$ although the probabilities were between $40 \%$ and $60 \%$, indicating less exposure to water deficits for the species established in these zones. Under the average conditions in the municipality and considering factors such as soil, water deficit, and coverage, these areas have a lower agroclimatic risk for goat grazing and for the establishment of agricultural species that would ensure food security in the region.

Nearly 75,000 ha in each four-month period corresponded to "areas limited by low or no current vegetation coverage and with potential for the establishment of vegetation cover" (Tab. 4). In these areas, there is currently not adequate plant cover for goat grazing. They are bare lands where the frequency of water deficits is less than $60 \%$ and where the soil, despite its limitations (at the effective depth level, texture, $\mathrm{pH}$, compaction, drainage, salinity, and sodium), would allow for the establishment of a vegetation cover. The recommendation is to start planting shrubs, grasslands, and adapted forest species that could serve as a food source for goats in the medium term.
Around 21,000 ha scattered throughout the municipality were identified as having the greatest risk, i.e. cataloged as "areas not recommended for goats". There, the establishment of agricultural crops or even minor species is not recommended. The areas known as "areas for current goat use with soil limitations for the establishment of vegetation cover", which covered more than $40 \%$ of the municipality, have low and continuous coverage (mainly grasslands and shrubs) that can supply food to animals in the short term.

\section{Extreme water deficit condition}

When analyzing "areas recommended for the production of goats and with potential for the establishment of vegetation cover", under extreme water deficit conditions in the two evaluated periods, reductions of $35 \%$ (period JFMA) (Fig. 6C and D) and $55 \%$ (period ASON) were found, as compared to the 170,000 ha identified as having an average water deficit. During the first four-month period, approximately 130,000 ha were in this category.

Because of the significant reductions in the area with a lower agroclimatic risk, the ASON period was the 
most critical one since about 90,000 ha were no longer recommended for goat production, becoming "areas limited by high exposure to water deficit", where the high frequency of extreme water deficit conditions limits the establishment of plant species.

In general, the areas with the greatest agroclimatic risk for extreme water deficit conditions totaled between 306,000 and 513,000 ha for the JFMA and ASON periods, respectively (Tab. 4). This increase in the risk area for goat production resulted from the greater impact of extreme water deficit phenomena during the second semester of year. The greatest alteration in precipitation volume and maximum temperature were recorded between June and December as a result of events such as El Niño.

Vegetation growth and development varied depending on the humidity conditions and limitations in the soils for the establishment of vegetation cover. The nutritional status of goats was affected, generating malnutrition and low meat and milk production, which are main products of goats in this area (Roncallo, 2002). Furthermore, malnutrition conditions can be exacerbated by a lack of management practices (Islam et al., 2002).

Goat and sheep production systems have a wide range of adaptation under favorable and extreme weather conditions (Arbiza, 1986; Devendra, 2006, cited by Grajales et al., 2011); frequently, they are established in areas with climatic limitations (dry areas with low rainfall) and areas of low vegetation. However, the success of feeding these species is based on the efficient selection of the most nutritious parts of herbaceous and shrubby vegetation with a lower water requirement because of the ability to concentrate and reduce the volume of urine, evaporation of feces, and reduction of water losses through evaporation, as reflected in a higher digestibility of fiber-rich foods (Grajales et al., 2011). Therefore, it is necessary to generate alternatives for the management of goats and sheep that guarantee a food supply and security in communities since this production system represents $60 \%$ of the meat diet of the inhabitants (Márquez, 2006).

Agroclimatic suitability zoning is in line with the proposal by Gupta (1992) and the concept of zooclimatic regions, incorporating factors inherent to the development of a goat-productive system, such as species preference and ecological niches, considering the diversity of biomass sources such as trees, shrubs, or pastures (protein banks). Moreover, the developed zoning incorporates water balance and land cover elements, as does the zoning used in pasture suitability studies, such as those developed following the FAO method (1991), where emphasis is placed on forage

Table 4. Agroclimatic suitability for goats in the municipality of Uribia under two water deficit conditions.

\begin{tabular}{|c|c|c|c|c|}
\hline \multirow[b]{2}{*}{ Category } & \multicolumn{2}{|c|}{ Average water deficit } & \multicolumn{2}{|c|}{ Extreme water deficit } \\
\hline & $\begin{array}{c}\text { JFMA area } \\
\text { ha (\%) }\end{array}$ & $\begin{array}{c}\text { ASON area } \\
\text { ha (\%) }\end{array}$ & $\begin{array}{c}\text { JFMA area } \\
\text { ha (\%) }\end{array}$ & $\begin{array}{c}\text { ASON area } \\
\text { ha (\%) }\end{array}$ \\
\hline $\begin{array}{l}\text { Areas recommended for goat production with } \\
\text { potential for the establishment of plant cover }\end{array}$ & $\begin{array}{c}171,440.0 \\
(21.8 \%)\end{array}$ & $\begin{array}{c}172257.6 \\
(21.9 \%)\end{array}$ & $\begin{array}{c}129,795.5 \\
(16.5 \%)\end{array}$ & $\begin{array}{c}77,485.5 \\
(9.8 \%) \\
\end{array}$ \\
\hline $\begin{array}{l}\text { Areas limited by low or no current vegetation } \\
\text { cover with potential for plant cover establishment }\end{array}$ & $\begin{array}{c}75,387.7 \\
(9.6 \%)\end{array}$ & $\begin{array}{c}76261.7 \\
(9.7 \%) \\
\end{array}$ & $\begin{array}{c}57,575.1 \\
(7.3 \%) \\
\end{array}$ & $\begin{array}{c}30,157.4 \\
(3.8 \%) \\
\end{array}$ \\
\hline $\begin{array}{l}\text { Areas for current goat use with soil limitations for } \\
\text { the establishment of plant cover }\end{array}$ & $\begin{array}{c}324,686.7 \\
(41.2 \%)\end{array}$ & $\begin{array}{c}325121.0 \\
(41.3 \%)\end{array}$ & $\begin{array}{c}292,251.2 \\
(37.1 \%)\end{array}$ & $\begin{array}{c}164,756.9 \\
(20.9 \%)\end{array}$ \\
\hline Areas limited by high exposure to a water deficit & $\begin{array}{l}817.6 \\
(0.1 \%)\end{array}$ & - & $\begin{array}{c}42,462.2 \\
(5.4 \%)\end{array}$ & $\begin{array}{l}94,772.1 \\
(12.0 \%)\end{array}$ \\
\hline $\begin{array}{l}\text { Areas for current goat use with low potential for } \\
\text { the establishment of plant cover }\end{array}$ & $\begin{array}{l}434.3 \\
(0.1 \%)\end{array}$ & - & $\begin{array}{c}32,869.8 \\
(4.2 \%)\end{array}$ & $\begin{array}{c}160,364.0 \\
(20.4 \%)\end{array}$ \\
\hline Areas not recommended for sheep and goats & $\begin{array}{c}213,147.6 \\
(27.1 \%)\end{array}$ & $\begin{array}{c}212273.6 \\
(27.0 \%)\end{array}$ & $\begin{array}{c}230,960.2 \\
(29.3 \%)\end{array}$ & $\begin{array}{c}258,377.9 \\
(32.8 \%)\end{array}$ \\
\hline Total area & & & & \\
\hline
\end{tabular}

JFMA: dry period from January to April; ASON: rainy period from August to November 


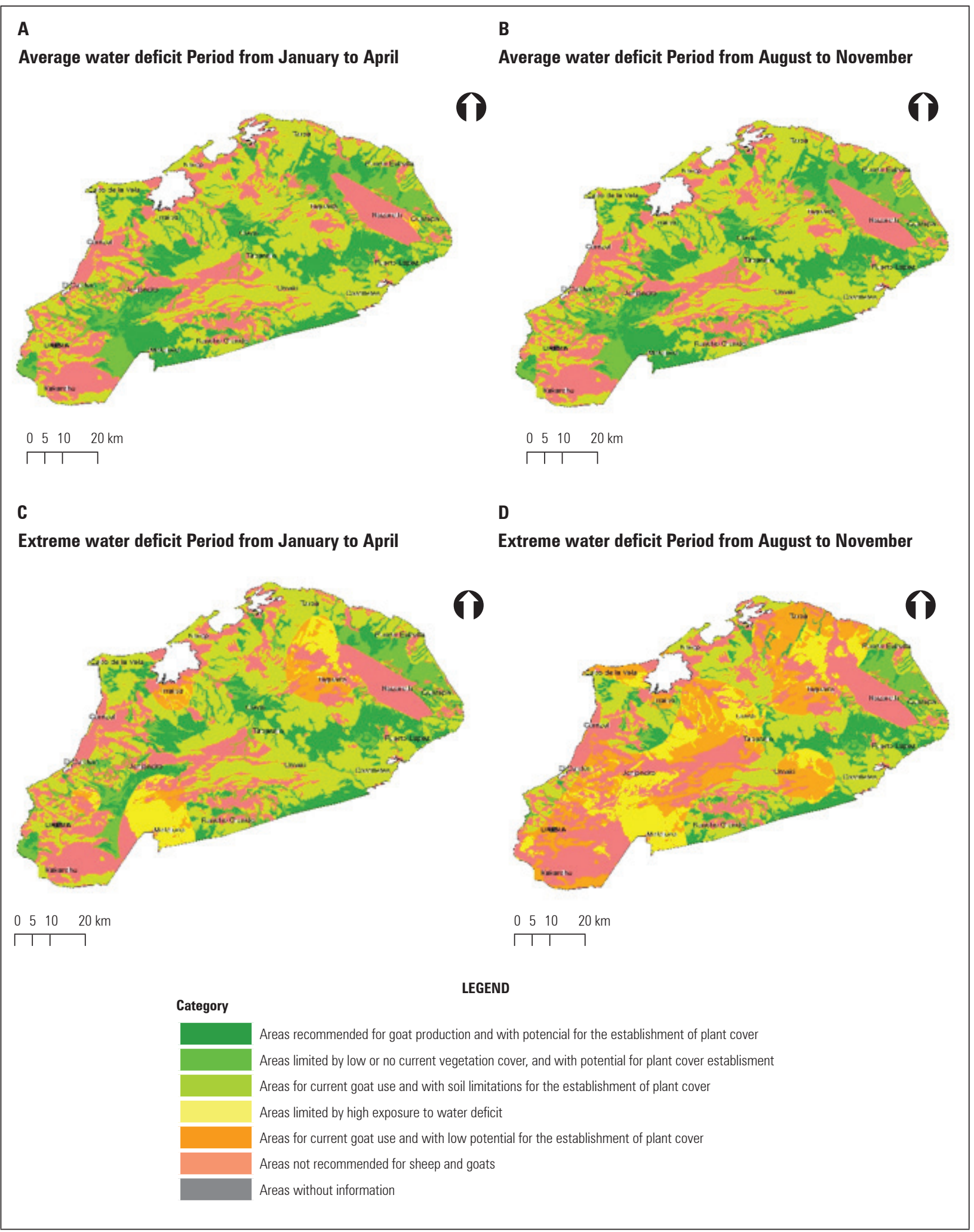

Figure 6. Agroclimatic suitability for goat production systems under: A) average water deficit conditions in the JFMA period; B) average water deficit conditions in the ASON period; C) extreme water deficit conditions in the JFMA period, and D) extreme water deficit conditions in the ASON period. 
production, water resources, and soil sensitivity to erosion (Amiri et al., 2012; Keno and Suryabhagavan, 2015). Although agroclimatic suitability zoning is a characterization tool, it is more accurate if there is soil, climate, and land cover data on detailed scales. In addition, it must be accompanied by feedback from system information that allows decisions to be made (from producers to rural planners).

\section{CONCLUSIONS}

In the municipality of Uribia, under average waterdeficit conditions, around 171,000 ha were identified as having the lowest agroclimatic risk, recommended for goat production with the potential to establish plant cover. Furthermore, 75,000 ha were identified as areas with the potential for the establishment of vegetation cover.

Under extreme water deficiency conditions, the recommended areas for goat production varied according to the four-month period (the highest and lowest volume of average rainfall). The largest available area was in the JFMA (January to April) period (approximately 130,000 ha), while for the ASON (August to November) period, the available area was much smaller (approximately 77,000 ha), showing the impact of an extreme water deficit phenomenon in the second semester, where the average rainfall volumes were drastically reduced.

Currently, most of the producers are located in areas with limited soil conditions that are not recommended for this land use because of average water-deficit conditions and low extreme water-deficit conditions that are subject to high exposure to water-deficit conditions and are strongly limited by soils, with little food source availability. Local adaptation strategies need to be developed to mitigate the impact of these conditions, identify alternative areas for mobilizing ethnic communities and minimize animal losses and risks for food security, thereby improving the livelihood of the locals.

\section{ACKNOWLEDGMENTS}

This study is the product of research carried out under Association Agreement No. 002 of 2013, entitled "Reducción del riesgo y adaptación al cambio climático" [Risk reduction and adaptation to climate change], signed between Fondo Adaptación and Corporación Colombiana de Investigación Agropecuaria
- Agrosavia. The authors thank the Agrosavia's Agroclimatology team for providing the data.

Conflict of interest: this manuscript was prepared and reviewed with the participation of all authors, who declare that there exists no conflict of interest that puts the validity of the presented results at risk.

\section{BIBLIOGRAPHIC REFERENCES}

Allen, R.G., L.S. Pereira, D. Raes, and M. Smith. 1998. Crop evapotranspiration, guidelines for computing crop water requirements. FAO, Rome.

Amiri, F., A.R. Shariff, and T. Tabatabaie. 2012. Monitoring land suitability for mixed Livestock grazing using geographic information system (GIS). pp. 241-266. In: Alam, B.M. (ed.). Application of geographic information systems. Institute of advance technology (ITMA), Faculty of Engineering, University Putra Malaysia, Serdang, Malaysia. Doi: 10.5772/47939

Arbiza, S. 1986. Producción de caprinos. AGT, México D.F.

Arce, C. and E. Uribe. 2015. Managing vulnerability and boosting productivity in agriculture through weather risk mapping: A guide for development practitioners. Agriculture Global Practice Technical Assistance Papers. World Bank, Washington, DC.

Basualdo, A., M. Berterretche, and F. Vila. 2015. Inventario y características principales de los mapas de riesgos para la agricultura disponibles en los países de América Latina y el Caribe. IICA, San Jose.

Brown, G. and C.M. Raymond. 2014. Methods for identifying land use conflict potential using participatory mapping. Landsc. Urban Plan. 122, 196-208. Doi: 10.1016/j.landurbplan.2013.11.007

Brunini, O., J.R. Zullo, H.S. Pinto, E.D. Assad, E. Sawazaki, A.P. Duarte, and M.E.Z. Patterniani. 2001. Riscos climáticos para a cultura do milho no estado de Sao Paulo. Rev. Bras. Agron. 9(3), 519-526.

Cleves-Leguízamo, J.A., J. Toro-Calderón, L.F. Martínez-Bernal, and T. Loeón-Sicard. 2017. La Estructura Agroecológica Principal (EAP): novedosa herramienta para planeación del uso de la tierra en agroecosistemas. Rev. Colomb. Cienc. Hortíc. 11(2), 441-449. Doi: 10.17584/rcch.2017v11i2.7350

Corpoica, Corporación Colombiana de Investigación Agropecuaria. 2016. Plan de manejo agroclimático del sistema productivo de ganadería ovino-caprina, municipio de Uribia, departamento de La Guajira. Mosquera, Colombia.

DANE, Departamento Administrativo Nacional de Estadística. 2014. Censo nacional agropecuario 2014. In: https://www.dane.gov.co/index.php/estadisticaspor-tema/agropecuario/censo-nacional-agropecuario-2014; consulted: April, 2019. 
Eslava, J.A. 1993. Climatología y diversidad climática de Colombia. Rev. Acad. Colomb. Cienc. Ex. Fis. Nat. 18(71), 507-538.

FAO. 1976. A framework for land evaluation. Soils Bulletin 32. Soil Resources, Management and Conservation Service, FAO Land and Water Development Division, Rome.

FAO. 1991. Guidelines: land evaluation for extensive grazing. FAO Soils Bulletin 58. FAO, Rome.

FAO. 1996. Agro-ecological zoning guidelines. FAO Soils Bulletin 73. Soil Resources, Management and Conservation Service, FAO Land and Water Development Division FAO. FAO, Rome.

Field, C.B., V. Barros, T.F. Stocker, Q. Dahe, D.J. Dokken, K.L. Ebi, M.D. Mastrandrea, K.J. Mach, G.-K. Plattner, S.K. Allen, M. Tignor, and P.M. Midgley. 2012. Informe especial de los Grupos de trabajo I y II del Grupo Intergubernamental de Expertos sobre el Cambio Climático, Cambridge University Press, Cambridge and Nueva York.

Fischer, M. and S.H.V. Velthuizen. 2002. Climate change and agricultural vulnerability. International Institute for Applied Systems Analysis; World Summit on Sustainable Development, Johannesburg.

Gelcer, E., C.W. Fraisse, L. Zotarelli, F.R. Stevens, D. Perondi, D.D. Barreto, H.A. Malia, C.C. Ecole, V. Montone, and J. Southworth. 2018. Influence of El Niño-Southern oscillation (ENSO) on agroclimatic zoning for tomato in Mozambique. Agric. For. Meteorol. 248, 316-328. Doi: 10.1016/j.agrformet.2017.10.002

Grajales, H.A., D.C. Moreno, and B.J. Atuesta. 2011. Guía técnica de producción ovina y caprina: I. Aspectos favorables y desfavorables para la producción ovina y caprina. International Print, Bogota.

Gupta, A.K. 1992. Integration of livestock with agro-climatic zone-based land use planning. Livestock Res. Rural Dev. 4(1).

IDEAM, Instituto de Hidrología, Meteorología y Estudios Ambientales. 2012. Mapa de coberturas de la tierra metodología corine land cover adaptada para Colombia escala 1:100.000 (Período 2005 - 2009). Bogota.

IGAC, Instituto Geográfico Agustín Codazzi. 2009. Estudio general de suelos y zonificación de tierras del departamento de La Guajira. Bogota.

Islam, M.R., M.M. Rahman, M. Mahbubur, and M.A. Zaman. 2002. Effect of agro-ecological zones, farm category and season on feeds and feeding of large ruminants in rural Bangladesh. Asian-Aust. J. Anim. Sci. 15(5), 643-649. Doi: 10.5713/ajas.2002.643

Keno, B. and K.V. Suryabhagavan. 2015. Rangeland suitability evaluation for livestock production using remote sensing and GIS techniques in dire district, southern Ethiopia. GJSFR-H 15(1), 11-25.
Kim, I. and S. Arnhold. 2018. Mapping environmental land use conflict potentials and ecosystem services in agricultural watersheds. Sci. Total Environ. 630, 827-838. Doi: 10.1016/j.scitotenv.2018.02.176

Kioko, J., J.W. Kiringe, and S.O. Seno. 2012. Impacts of livestock grazing on a savanna grassland in Kenya. J. Arid Land 4(1), 29-35. Doi: 10.3724/SP.J.1227.2012.00029

Magrin, G. 2015. Adaptación al cambio climático en América Latina y el Caribe. Documento de proyecto CEPAL, Santiago.

Márquez, J. 2006. Protección a la producción de caprinos en La Guajira. Instituto Colombiano Agropecuario, Bogota.

Martínez, F.E., L.Y. Deantonio, G.A. Araujo, E.O. Rojas, D.A. Gómez-Latorre, D.F. Alzate, L.A. Ortiz, E. Aguilera, and J.F. Boshell-Villamarín. 2016. Agroclimatic zoning methodology for agricultural production systems in dry Caribbean region of Colombia. Agron. Colomb. 34(3), 374-384. Doi: 10.15446/agron.colomb. v34n3.59672

Mesa, O.J., G. Poveda, and L.F. Carvajal. 1997. Introducción al clima de Colombia. Imprenta Universidad Nacional de Colombia, Bogota.

Oba, G., E. Post, N.C. Stenseth, and W.J. Lusigi. 2000. The role of small ruminants in arid zone environments: A review of research perspectives. Ann. Arid Zone 39(3), 305-302.

Palmer, W. 1965. Meteorological drought. Research Paper No. 45. Weather Bureau, U.S. Department of Commerce. Washington, DC.

Pinilla, G. and S. Zuluaga. 2014. Notas sobre la vegetación desértica del Parque Eólico Jepírachi, Alta Guajira, Colombia. Rev. Acad. Colomb. Cienc. Ex. Fis. Nat. 38(146), 43-52. Doi: 10.18257/raccefyn.39

Roncallo, B. 2002. Origen y evolución de la caprinocultura colombiana. Medicina veterinaria y zootecnia en Colombia, trayectoria durante el siglo XX y perspectivas para el siglo XXI. Ed. Edivez, Bogota.

Shinde, A.K., S.A. Karim, S.K. Sankyan, and R. Bhalla. 1998. Seasonal changes in biomass growth and quality and its utilization by sheep on semi-arid Cenchrus ciliaris pasture of India. Small Rumin. Res. 30(1), 29-35. Doi: 10.1016/S0921-4488(98)00087-X

Steinfeld, H., C. De Haan, and H. Blackburn. 1996. Livestock-environment interactions: Issues and option. Commission of the European Commission Directorate-General for Development. Food and Agriculture Organization of the United Nations, The United States Agency for International Development and the World Bank. Fressingfield, Eye, Suffolk, UK.

Zhang, J., L. Zhang, L. Welling, O. Yue, and W. Xiao. 2014. Livestock-carrying capacity and overgrazing status of alpine grassland in the Three-River Headwaters region, China. J. Geogr. Syst. 24(2), 303-312. Doi: 10.1007/s11442-014-1089-z 